\title{
Developing Islamic City through Network-of-Mosque (NoM)
}

\author{
Ammar Ihsan Nasution, Abdul Rahman Ahmad Dahlan, Ammar Ihsan Nasution, Muhammad Iqbal Husaini, \\ Mohamed Hassan Ahmed \\ International Islamic University Malaysia (IIUM), Malaysia \\ erecsson20@yahoo.com
}

\begin{abstract}
Learning from the history, our prophet used mosque to provide many activities and served as community centre for the purpose of society welfare. Today, we can find the mosque everywhere but its function were limited and only used for religious and spiritual purposes. Thus, this conceptual program will develop the Islamic City through Network of Mosque. Network of Mosque can be used to create centre for transformation which can provide the services to the society. These services will include community classes, zakat collection and distribution, halal certification, and eating place for the hungry and needy. This conceptual program introduces to improve the quality of service through strategic partnership between government, industry, and society which will result to raise the entrepreneurs and lead to the prosperity. This program offers Quadruple Helix Model (QHM) which involves the Government, Academia, Industry, and Citizen as the main actor for this program. Nine blocks of Business Model Canvas (BMC) framework and Literature Review used as the methodology for this paper. To achieve its goals, this program collaborates and synergize with the Whole of Government (WoG). The findings of this paper show that the Mosque can facilitate and serve the society better by harnessing Network of Mosque, which guide to the developing Islamic City.
\end{abstract}

Keywords: Islamic city, Network of Mosque, Business Model Canvas, Society welfare, Quadruple Helix Model

\section{Introduction}

Today, people use mosque only for the purpose of Ibadah. But, we realize that Network of Mosque (NoM) has a great potential to improve social welfare for the society who live around the mosque. By harnessing Network of Mosque (NoM) we can help the people to save time without having to go to a government or industry building. Mosque committee will provide many kind of service such as for marriage class and education, hajj and umroh training, waqaf and zakat collection and contribution, Islamic learning, and more. Based on the Office for National Statistics (ONS) (Measures of National Well-being, 2014), there are ten factors to consider in order to measure the national wellbeing. From their graphic, health is one of the factors that are important for national wellbeing. From ONS National wellbeing graph, health, personal wellbeing, relationship, and education and skills are some of the factors that we need to understand. And Islamic city program can help the government to improve the national wellbeing from these factors. Islamic City developed to create the wellbeing for society. One of its programs is to provide medical service that will benefit for society's health and helping the government in providing the medical treatment to the society (Portal resmi Kementrian kesehatan Malaysia, 2014). Islamic city developed using Network of Mosque that will create the better relationship to the people around the mosque. Personal interaction between the society and committee can bring the positive impact and satisfy the customers (Azam, 2013). In education sector, Islamic City has a program to educate the people. Islamic city provide an online and offline class for Muslim and Non-Muslim society. Moreover, Islamic city developed to help people in their activities. With Islamic city, the personal wellbeing can be improved to create the happiness in the society.

Program Background: This paper proposed the developing of wellbeing by creating Islamic city harnessing of the Network of Mosque (NoM). Through our program we are trying to make a lot easier for the people. We propose Mosques to be our center services. Since we can find mosque everywhere, than we can provide many activities that can help more people. The focus targeted audiences of this program are all the people who live around the mosque interfaith everyone. This program has the potential to provide quality services for the society and improve the level of awareness's of the society. This can be achieved by providing certain services 
and programs, namely: marriage class and education, hajj and umroh training, waqaf and zakat collection and contribution, Islamic learning. This program synergize with the Whole of Government (WoG), where similar/related/cluster of government agencies collaborate to achieve the goals (Habiba, 2013). Besides that, this program also offered Quadruple Helix Model (QHM), which is a concept in innovation research that that integrates Government, Academia, Industry \& Citizen/Community (Ania, 2013). Islamic city project provides services to help the Muslim society, these services include immigration problems and counselling, legal advice, marriage counselling, marriage arrangement counsellor and setter-up information, family planning advice, making the Muslim communities aware of help and opportunities available for them, have some sort of facilities to the help the destitute, temporarily homeless. We also try to organize a group of people for welcoming visitors to the mosque and advertising mosque functions to the community. Then we can reach our vision as the religion of "Rahmatan Lil Alamin" (mercy to all mankind).

Program Objectives: The main objective for this paper is to propose the creation of Islamic city to create the wellbeing for society. Islamic city defined as a city where the communities are well advanced in terms of education, economic, services and social lives according to Islamic traditions (Rabah, 2002). By harnessing Network of Mosque (NoM) we can help the people to save time without having to go to a government or industry building by providing the service for them. Mosque committee will provide many kind of service such as for marriage class and education, hajj and umroh training, waqaf and zakat collection and contribution, Islamic learning, and more. Islamic City can collaborate with Lembaga Tabung Haji to provide the hajj, umroh and other Islamic activities (Bimbingan - Lembaga Tabung Haji, 2014). These can make the Muslim society more convenient on performing their obligation as a Muslim. As we know, almost all of the services that have been mentions are very rare to be seen at the similar place/centre, the Muslim society might spent a huge cost to reach each of the service. This is an opportunity for the Muslim to centralize all of the Muslim activities in one place as we call it as an "Islamic City". In Islamic city, Islamic scholars around the world are encourage to be contributed in Islamic city in order to give sermons for people who are needed or lack of Islamic knowledge. This Islamic city can be accessible all over the world but also played a very important role in spreading Islam and also to clarify the misconceptions of non-Muslims about true of Islam.

This project will bring the wellbeing to the society. This program offers Quadruple Helix Model (QHM) which involves the Government, Academia, Industry, and Citizen as the main actor. It will cooperate with a government institution such as Jabatan Kebajikan Malaysia (JKM), Ministry of Health Malaysia (KKM), Jabatan Kemajuan Islam Malaysia (JAKIM), and Tabung Hajj department of Malaysia. Besides, this program will collaborate with hospitals and clinics in Malaysia to provide and improve the health service to the society. For event development, this program will include the public company such as wedding event organizer that will help society in managing and organizing the wedding activities. For educational cluster, this program will collaborate with universities in Malaysia and the society experts who want to be volunteers. As the main actor in this program, mosque committee has a significant impact to handle the program through the network of mosque.

\section{Literature Review}

The world mosque or masjid taken from Arabic language which is sujud (sajada). It means the devoted, loyal, and with bowed heads with full of respect and reverence. The mosque use for many function, not only for worship but also to seek for knowledge, Muslim centre activities, as well as the centre developing economic of the ummah. According to Omar Bakri (Muhammad, O. B, n.d.) on his book The Role of Mosque explained that in the prophet time, there are 20 activities/tasks which we expect from the mosque. Some of the activities that expected from the mosque are the mosque as the Judiciary Court, the mosque as the headquarters of the Islamic State's supreme leadership, the mosque as a section of the Department of Information and Culture, the mosque as the University for Learning and Teaching, the mosque as the platform for oratory, eloquence and poetry, the mosque as the hospital where casualties of war are treated, the mosque is a home and refuge for the poor, needy and the travellers, the mosque as an eating place for the hungry and the needy and the Mosque as a place for consultation and exchanging views. From the points above, only few activities that handled by the mosque in this time. Today, the Mosque do not act as the Muslim centre anymore, Muslim uses mosque as the place for religious practices only. We as Muslim should expand the culture of the Mosque 
based on the prophet era, as a key role of Muslim activities. We need to return the Mosque to its original function.

In this globalization era, we may utilize the Mosque as the Muslim centre in order to develop Islamic country. We can have many Islamic activities that can be handled in the mosque. These activities can be implemented in different program. We can harnessing the Network of Mosque to establish the Mosque as a centre of education, marriage course, zakat collection and distribution, Umroh and Hajj training, halal certificate distribution, Islamic seminars, and providing other value-added services to the people who live around the mosque. But, in order to develop Islamic city, all stakeholders must give its contribution including Government, Mosque committee, company, and the society (Habiba, 2013). Then, we can improve the social welfare for those people who live around the mosque. In Malaysia, Urban Transformation Centre or UTC becomes one of the good examples to improve the social welfare for people around him. UTC is one of the government effort and initiatives providing the urban community with key government and private sector services under one roof. With UTC, people around can come for many activities. The services that UTC provides are, National Registration Department, MyEg, Public Transportation Commission (SPAD), Immigrations Departments, Department of road transportation (JPJ), Lembaga Hasil Dalam Negeri (LHDN), and Companies Commissions of Malaysia (Treasury-UTC, 2012). The main purpose of UTC is to provide the business service centre that brings the social welfare to the society. Based on the News Strait Times dated 6 of August 2014, the government targeted 123000 business registrations for the Goods and Service Tax (GST) which bring the social welfare for those who life around UTC(Dasspetaling, 2014).

Currently, the coverage of UTC is still not nation-wide. Thus, the researcher suggests the Network of Mosque as the solution to improve the social welfare because we can find the mosque even in remote areas. We can use this network to develop Islamic country that will served the Ummah better just like what the sahabah did in the prophet era. We can also can learn from Smart city concept. Smart city is the concept is really a framework for a specific vision of modern urban development. Smart city recognizes the growing importance of information and communication technologies (ICT) as drivers of economic competitiveness, environmental sustainability and general liveability (Alcatel-Lucent, 2012). Smart cities are expected to be the key to combine a sustainable future with continued economic growth and job creation which also bring the welfare to the society. The main purpose of Islamic city is to establish a "user-driven" based development model to enhance the community quality of life. Islamic City project combines and merges government agencies services and voluntary services in an easy way, saving money and time. Islamic City project will connect all the Mosques in Malaysia through Network of Mosque (NoM) and provide Services for the Society. As we can find mosques almost everywhere in Malaysia, we decided to use NoM to create an Islamic city which the basic services will be delivered through it. The activities that will be served in the Islamic city project through the Network of Mosque are:

Community classes: Community classes' purposes to educate people become better. This will help Muslim youth to learn how to read the Quran, learn about Islamic history, manners and Etiquettes, traditions of the holy prophet (SAW), Fiqh as well as memorization of the Quran. And for the Non-Muslim, they may joined the language class. So, they can learn English and Arabic language that can be benefit for their future. We can have Muslim communities who are fluent in Arabic and English to teach them. Furthermore, we also have special classes for Elders women and men separately. As the fact is, that in our societies we find many elders who cannot even read the Quran. We will provide special classes teaching how to read the Quran properly and memorizing the small surah's of the Quran so that they can read in their prayer. This will also help the elders invest their time in a good matter and gives them the opportunity to meet each other and strengthen the bond of Muslim hood. All the teaching services mentioned above not only for the Muslims. We will also encourage and welcome the non-Muslims to join these classes. This can be a good example of Da'wah.

Marriage-related services: Marriage is the Sunnah of our prophet. Based on themalaymailonline.com dated march, 3rd 2014 there are 148,806 Muslim marriages in 2012, according to the Department of Islamic Development Malaysia (JAKIM) and a total of 65,993 marriages were registered in 2012 (Su-lyin, 2014). This number shows that there are the significant numbers of marriage in every year. With Islamic City, we can help people who want to get married by providing marriage service. These services include marriage 
registration, certification and wedding event. For marriage event, NoM will also cooperate with other wedding organizer. Besides, Islamic City also provide birth certification and marriage consultation.

Zakat and Waqaf collection and distribution: Zakat is the practice of taxation and redistribution, including benefits paid to poor Muslims, imposed upon Muslims based on accumulated wealth. It is obligatory for all who are able to do so, and it is considered to be a personal responsibility for Muslims to ease economic hardship for other Muslims to eliminate inequality among followers of Islam (Wikipedia, 2014). As the centre of Muslim community, Zakat can be collected through the mosque and it can distribute to the needy people around the mosque. This benefit will bring the wellbeing to the society who live around the mosque because the mosque committee know who are the needy and can distribute it to the right people.

Promoting Halal Product: Network of Mosque unable us to distribute and promote the halal product easily. One of the conceptual solutions for promoting halal product via Network of Mosque is an eHalal4All Program which aim to raising the economic and social status of rural communities/entrepreneurs in Sabah, Malaysia (Rahman, 2014). We can cooperate with JAKIM in order to succeed of their program in promoting Halal Product (Bantuan Kebajikan - Jabatan Kebajikan Masyarakat Malaysia, 2014). Thus, it can improve the wellbeing for the society.

Sermons and Islamic lecturers: As the centre of Muslim society, Mosque can be used to spread Islamic value. One of the ways to spread Islamic value is through the lecturer and sermons. Mosque also can be used as the place for those who want to convert to Islam, and people who just converted to Islam can present in Islamic lecturer and learn basic Islamic activities such as how to perform wudhu, prayer, and so on.

Umroh and Hajj learning: With harnessing the Network of Mosque, government can easily manage and monitor the people who intent to perform Umroh and hajj easily. Mosque committee can cooperate with Tabung Hajj for Umroh and Hajj learning activities. It included the registration of Hajj and Umroh, the seminar about Hajj and Umroh, learning and guidance and counselling about Hajj and Umroh. Besides that it also helps the people to apply for passport, health test, payment of the costs, and the updated information about hajj.

Medical centre: Based on the WHO Statistics, Malaysia has a big number for the total expenditure on health per capita in Malaysia which is $\$ 692$ (WHO Malaysia, 2012). With this conceptual solution, mosque can be used as the medical centre. Thus, Muslims without insurance or those who are in need of emergency help can receive treatment. It can be conducted by cooperating with the minister of health Malaysia and the nearest hospital to the mosque. With Network of Mosque, people can save their time and money because they do not need to go further if they need any treatment.

Home for the disable, needy, and traveller: Jabatan Kebajikan Masyarakat (JKM) declared that one of their objectives is to help the disable people (Bantuan Kebajikan JKM, 2014). With network of Mosque, we can cooperate with JKM to provide the home for disable people and needy. Not only that, mosque can be used as the home for travellers, especially for those who spread the Islamic messages (da'wah).

Eating place for the hungry and needy: Today, Malaysian government concerned and makes the poverty eradication as one of the primal priority (Rahman, 2014). In Islamic city, we can help government to control and help the disable, hungry and needy people. Based on the Department of Statistics Malaysia, the poverty rate went up from 3.6 percent in 2007 to 3.8 percent in 2009 while the hardcore poverty rate remained at 0.7 percent (Suara Sarawak, 2012).Thus, by utilizing the network of mosque the Islamic City can collaborate with government institution like JKM to feed the disable, hungry, and needy people. People may also give their Sadaqah to the mosque to feed the needy. Moreover, we may have the fasting and future together as the weekly agenda in the mosque so that we can help the people around us. 
Figure 1: Islamic City Portal (Homepage)

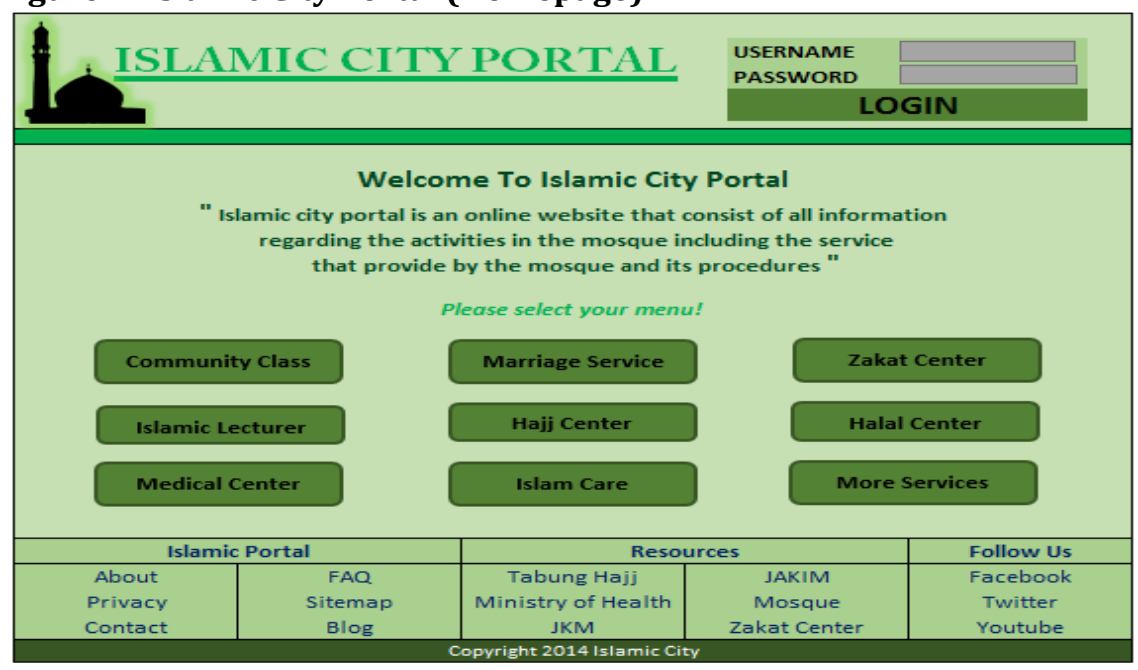

\section{Figure 2: Islamic City Portal (Menu Page)}

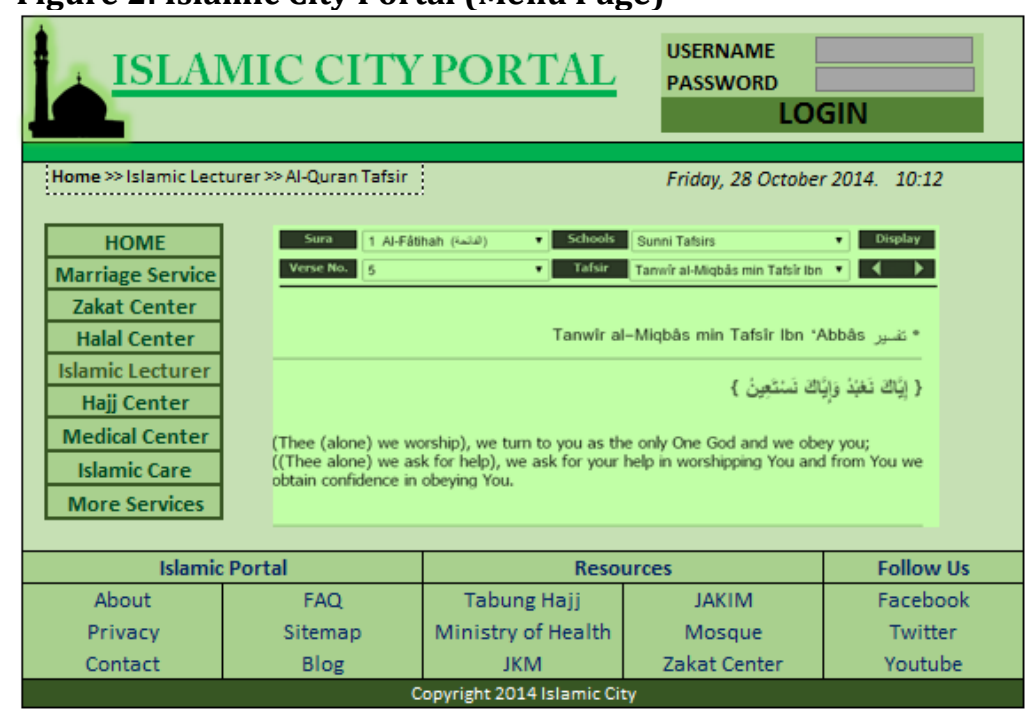

Islamic city portal: Islamic city portal is an online website that consists of all information regarding the activities in the mosque including the service that provide by the mosque and its procedures. With Islamic city portal, people can get and update any information directly through their gadget. Islamic portal also provided articles that can be read for free by visitor. Moreover, it also has an online learning that provided to the people who want to learn Islam via internet. People must pay subscription fees in order to get these features. The ten activities above can improve and guide to the wellbeing of society. With network of Mosque, it is not impossible to develop Islamic City. The current and future trend of people to come to the mosque at least for performing five times prayers. At this five times, people come and gather to perform Islamic rituals. And people gathering may have a great potential, not only for silaturrahmi but also to build and improve their life. Mosque that build in the centre of the city or village and can be used as central of activities because of its strategic location. With Network of Mosque, we can provide more service and activities to the society around the mosque. Then, we can improve the wellbeing of the society.

\section{Proposed Conceptual Solution}

In order to create the Islamic city, we can utilize the use of Network of Mosque to develop wellbeing to the society. Ibnu Khaldun as one of Islamic Scholar states that entrepreneur is seen as a knowledgeable individual and is instrumental in the development of a city-state where enterprises will emerge (Mervyn, 2007). We can 
practice this concept to the network of mosque to improve our social welfare. Managing and creating the Mosque as the Community center can help people in many activities. Moreover, people can find the mosque everywhere which will reach more targeted audience that will cover more people in the society. In Islamic City, we also come with an online portal that include all information and activities that related to the Islamic City activities. This portal will help people to view and get the updated news about the mosque and its activities. It will include the procedure to apply marriage certificate, halal promotion, and Learning material. Also it will display the event that will be hold by the mosque committee such as seminar information and wedding event. Not only that, it also will include the khutbah, Islamic teaching, and Islamic articles that can be read by the society for free. The society can also do an online consultation via Islamic city portal. Thus, it can develop the wellbeing of people and make society's activities become easier. In order to achieve its goal, this program will collaborate with many government agencies including Islamic Department of Malaysia, Ministry of Health Malaysia, Jabatan Kebaikan Masyarakat Malaysia, and Tabung Haji Malaysia. Also it will collaborate with the university and academia in order to provide Islamic activities such as sermons and Quranic learning. In industry and Malaysian company, this program also collaborates to achieve its goal as Islamic City, such as a wedding organizer. Mosque committee plays an important role in Islamic City. They will handle the activities with collaboration with the government, industry, academia, and society who will use the system.

Figure 3: Business Model Canvas (BMC) for Islamic City Program

The Business Model Canvas

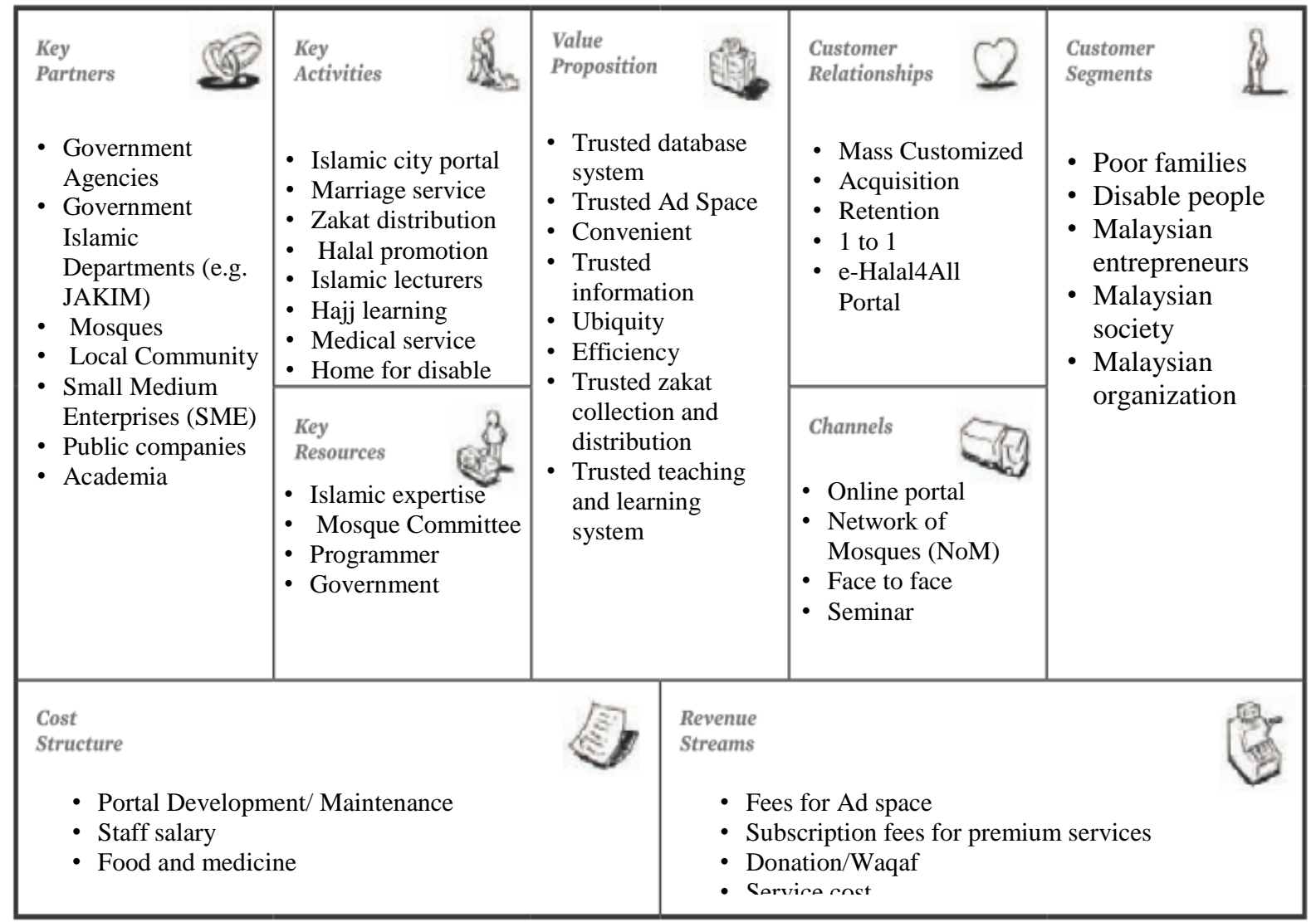

Customer Segments: The Customer Segments is the society or the organization that involves and has a contribution in developing Islamic city. The customer segments included:

- Poor families

- Disable people

- Malaysian society

- Malaysian organization/companies

- Malaysian entrepreneurs 
Cost Structure: The Cost Structure is the cost amount that must be paid from the activities that utilized during developing Islamic city. The Cost structure included:

- Portal development and maintenance.

- Staff salary

- Food for the poor and needy

- Seminar cost

- Medicine

Revenue Streams: The Revenue Streams is the revenue that generates from the customer to cover the cost structure in developing Islamic city. The revenue streams included:

- Service fees for marriage and hajj program

- Proposal funds from the government

- Freemium service for Online Islamic lecturers and learnings

- Subscription fees for those who want to subscribe to an online learning, such as the subscription fee for those who want to get the weekly Islamic courses through Islamic portal website.

- Booking fees for those who want to book the mosque facilities such as for wedding party

- Advertising fees for advertisement that related to Islamic City

- Seminar fees for those who want to join the seminar

- Donation and Waqaf from the society.

Key Partners: The Key Partner describes the people or group of people who that act as partners order to run the Islamic City Program. The key partners include:

- Public company such as wedding organizer in Malaysia to organize marriage related activities.

- Tabung Hajj department of Malaysia for Hajj and Umroh program

- Society that want to be volunteer

- Mosque committee

- University in Malaysia for running the community class and educational program

- Hospital in Malaysia for treatment and medical related activities

- Ministry of Health Malaysia for medical related activities

- Jabatan Kabajikan Masyarakat (JKM) for organizing the home for disable and needy activities

- Islamic Department of Malaysia such as JAKIM to qualify the application of Halal certification

Key Activity: The Key Activities is the main activities that provide in Islamic City to develop the wellbeing to the society. The key activities included:

- Provide Community classes

- Provide Marriage service

- Collect and Distribute zakat and Waqaf to the right people.

- Provide Halal certification

- Provide Sermons and Islamic lecturers

- Provide Umroh and Hajj learning

- Provide Medical service

- Home for the disable, and needy

- Eating place for the hungry and needy

- Provide Islamic city portal

Key Resources: The Key Resources describes the most necessary assets required to process Islamic City Program work. The key resources such as:

- Islamic expertise on marriage, hajj, zakat and knowledge of Islam.

- Tabung haji is required in order to support the financial of candidate of hajj

- Companies that can provide the weeding party

- Programmer that can build an Islamic city portal

- Islamic department of Malaysia (JAKIM) for collaboration in Islamic related activities

- Jabatan Kebaikan Masyarakat (JKM) to support the home and eating place for the needy

- Ministry of Health Malaysia (KKM) to collaborate in the medical center program 
Value Preposition: The Value Propositions is the value of the services that provided in the Islamic society in order to satisfy the customer. The value prepositions included:

- Convenient and customer can save their time

- Trusted zakat collection and distribution

- Trusted database system

- Trusted ad space

- Trusted information distribution

- Trusted teaching and learning system

- Ubiquity, because people can find the mosque everywhere and at anytime

- Efficiently in processing marriage because we are providing almost all of the services which are the regulation of marriage in Malaysia such as HIV test, Seminar, Wedding.

Customer Relationship: The Customer Relationships is the type of relationship that used in the Islamic city Program. The purpose of this program is to provide the efficiency of different aspect of activities, including marriage, umroh, hajj, learning, waqaf, zakat and other related activities for the Muslim society.

Channels: The Channels are the parties that communicate in Islamic city program in order to achieve its Value Proposition. The Channels included:

- Network of Mosque

- Islamic City Portal

- Face to face

- Seminar

\section{Conclusion and Future Works}

In the prophet era the utilizing of mosque not only for Ibadah but also for spread knowledge and dakwah. Nowadays, the function of mosque is not well optimized like in the during the prophet era. To improve the function of Ibadah, mosque also can be used as a centre of Islamic activity. Mosque not only utilized for Ibadah but also for the activity that can help ummah which spreading knowledge, contribution of Zakat and many others. In order to reach the Islamic city, the Network of Mosque is one of the ways that can be used. In Islamic City, we also come with an online portal that include all information and activities that related to the Islamic activities. Indeed, another program and tools also can be added for future works for example, in order improve the development of Islamic city we might also utilize social networking as a media of communication. Islamic City program should provide video, cassette and CD libraries, with equipment to use them. This is a very important facility that every mosque should have. Another future work suggestion could be providing shelters for the visitors. Moreover, provide Muslim shop, where they can find Islamic Books, clothes, Islamic decorations. It would be a great idea if a Muslim Bookshop, cafeteria, and Halal food-store could be incorporated into the areas around the mosques.

\section{References}

Alcatel, L. (2012). Getting Smart about Smart Cities. Boulogne-Billancourt, Frence: Alcatel-Lucent.

Ania, F. (2013). Quadruple-Helix and its types as user driven innovation models. Triple Helix International Conference 2013

Azam, A. (2013). Financial Management Practices of Mosque in Malaysia. GJAT Malaysia, 3(1).

Bantuan Kebajikan - Jabatan Kebajikan Masyarakat Malaysia. (2014). Retrieved October 05, 2014, from http://www.jkm.gov.my/content.php?pagename=bantuan_kebajikan.

Bimbingan - Lembaga Tabung Haji. (2014). Retrieved October 06, 2014, from http://www.tabunghaji.gov.my/web/guest/bimbingan.

Dasspetaling, F. (2014). Govt targets 123,000 GST registrations. Retrieved from September 28, 2014, from: http://www.nst.com.my/node/20626.

Habiba, D. (2013). MyMosqueNet2Cloud Collaborative System: A network of mosques towards eradicating poverty in Malaysia. American Academic \& Scholarly Research Journal, 5(5).

Measures of National Well-being. (2014). Retrieved October 13, 2014 from http://www.neighbourhood.statistics.gov.uk/HTMLDocs/dvc146/wrapper.html. 
Mervyn, K. (2007). Handbook of Islamic Banking. Northampton, USA: Edward Elgar Publishing Muhammad, O. B. (n.d.). The Role of the Mosque. Al-Muhajiroun Publications.

Portal resmi Kementrian kesehatan Malaysia. (2014). Retrieved October 06, 2014, from http://www.moh.gov.my/index.php/pages/view/137.

Rabah, S. (2002). Foundation for Science Technology and Civilization: Introduction to Islamic city. Manchester, United Kingdom: FSTC Limited.

Rahman, A. (2014). Holistic Development of Human Talent - Leveraging On EMaarah Tuition Program through the Network of Mosque (Nom). IOSR Journal of Research \& Method in Education, 4(3), 60-68

Rahman, A. (2014). Enhancing Societal Wellbeing and Wealth Creation - Sewing Skills Programmed. IOSR Journal of Humanities and Social Science, 19(5), 117-122.

Suara Sarawak. (2012). Retrieved on 2014, November 5. from http://www.barubian.net/2012/07/malaysiasuffers-first-rise-of-poverty.html.

Su-lyin, B. (2014). One divorce in Malaysia every 10 minutes. Retrieved October 08, 2014, from http://www.themalaymailonline.com/malaysia/article/one-divorce-in-malaysia-every-10-minutes

Treasury-UTC 2013 [Brochure]. (n.d). Kuala Lumpur, Malaysia: UTC Center.

WHO Malaysia. (2012). Retrieved 2014 November 5 from http://www.who.int/countries/mys/en/.

Zakat (n.d.). In Wikipedia. Retrieved October 08, 2014, from http://en.wikipedia.org/wiki/Zakat. 